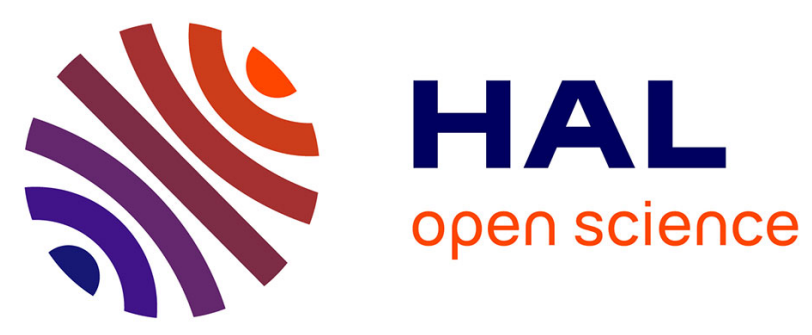

\title{
A meta-analysis of outcomes of in situ reconstruction after total or partial removal of abdominal infected aortic graft
}

Michel Batt, Fabrice Camou, Amandine Coffy, Patrick Feugier, Eric

Senneville, Jocelyne Caillon, Brigitte Calvet, Christian Chidiac, Frédéric

Laurent, Matthieu Revest, et al.

\section{To cite this version:}

Michel Batt, Fabrice Camou, Amandine Coffy, Patrick Feugier, Eric Senneville, et al.. A meta-analysis of outcomes of in situ reconstruction after total or partial removal of abdominal infected aortic graft. Journal of Cardiovascular Surgery, 2020, 61 (2), pp.171-182. 10.23736/S0021-9509.19.10669-6 . hal02049817

\section{HAL Id: hal-02049817 \\ https://hal-univ-rennes1.archives-ouvertes.fr/hal-02049817}

Submitted on 13 Mar 2019

HAL is a multi-disciplinary open access archive for the deposit and dissemination of scientific research documents, whether they are published or not. The documents may come from teaching and research institutions in France or abroad, or from public or private research centers.
L'archive ouverte pluridisciplinaire HAL, est destinée au dépôt et à la diffusion de documents scientifiques de niveau recherche, publiés ou non, émanant des établissements d'enseignement et de recherche français ou étrangers, des laboratoires publics ou privés. 


\section{A meta-analysis of outcomes of in situ reconstruction after total or partial removal of abdominal infected aortic graft}

Short Title: In Situ Reconstruction after Total or Partial Graft Removal.

Michel Batt ${ }^{* 1}$, Fabrice Camou ${ }^{2}$, Amandine Coffy ${ }^{3}$, Patrick Feugier ${ }^{4}$, Eric Senneville ${ }^{5}$, Jocelyne Caillon ${ }^{6}$, Brigitte Calvet ${ }^{7}$, Christian Chidiac ${ }^{8}$,Frederic Laurent ${ }^{9}$, Matthieu Revest $^{10}$, Jean Pierre Daures ${ }^{11}$, on behalf of the Research Group for Vascular Graft Infection ${ }^{12}$

${ }^{1}$ Department of Vascular Surgery, University Nice-Sophia Antipolis, Nice, France;

${ }^{2}$ Intensive Care Unit, Saint-Andre University Hospital, Bordeaux, France ; ${ }^{3}$ University Institute for Clinical Research. Laboratory of Biostatistics and Epidemiology, Montpellier, France; ${ }^{4}$ Department of Vascular Surgery, University Claude Bernard Lyon 1, Hospices Civils de Lyon, France; ${ }^{5}$ Infectious Diseases Department, Gustave Dron Hospital, Tourcoing, Lille 2 University, France; ${ }^{6}$ Bacteriology Department, University Hospital, Nantes, France; ${ }^{7}$ Anesthosiology Department, Béziers Hospital, Béziers, France; ${ }^{8}$ Infectious Deseases Department, Hospices Civils de Lyon, and International Center for Infectiology Research (CIRI), INSERM U1111, Lyon 1 University, Lyon, France; ${ }^{9}$ Bacteriology Department, International Center for Infectiology Research (CIRI), INSERM U1111, Lyon 1 University, Lyon, France; ${ }^{10}$ Infectious Diseases, and Intensive Care Unit, Pontchaillou University Hospital, CICINSERM 1414, Rennes 1 University, France; ${ }^{11}$ University Institute for Clinical Research. Laboratory of Biostatistics and Epidemology, Montpellier, France

*Corresponding author: Michel Batt, Department of Vascular Surgery, Pasteur 1 Hospital, University of Nice-Sophia Antipolis, 27 Corniche Andre de Joly, 06300 Nice, France.

E-mail: batt.m@outlook.com 


\section{Conflicts of Interest and Sources of Funding:}

The Research Group for Vascular Graft Infection received financial support from Novartis to travel to meetings for the study. Novartis had no role in the choice of the authors nor access to the author's conclusions until the work was completed.

$\mathrm{MB}$ received a research grant from Datascope and Novartis; FC received a research grant from Novartis, research investigator honoraria from Cubist, MSD, Sanofi, and Trius Therapeutics, payment for lectures from Novartis, Pfizer and Sanofi, and financial support to travel to international meetings from Astellas, Jansen, MSD, Novartis, Pfizer and Sanofi; PF received a research grant from Novartis; CC received a research grant from National Institutes of Health( NIH), Wellcome Trust, Howard Hughes Medical Institute( HHMI) and Research Council's UK( RCUK). FL received a research grant from Pfizer and Sanofi, payment for development of educational presentations from MSD, Novartis and Pfizer, and travel/accommodations/meeting expenses from Novartis, Basiles and MSD. MR received a research grant from Novartis, payment for lectures from MSD and Pfizer, and financial support to travel to international meetings from MSD. JPD and AC received fees for participation in statistical analysis. All other authors declare no competing interests. 


\section{ABSTRACT}

BACKGROUND. There is currently a lack of evidence for the relative effectiveness of partial resection (PR) and total resection (TR) before managing abdominal aortic graft infection (AGI). Most authorities agree that TR is mandatory for intracavitary AGI in patients with favorable conditions but there is an increasing number of patients with severe comorbidities for whom this approach is not suitable, resulting in a prohibitive mortality rate. The purpose of this study was to determine the most appropriate indication for TR or PR.

METHODS. A meta-analysis was conducted on the rates of early/late mortality, amputations and reinfection. A meta-regression was performed with 8 variables: patient age, male prevalence, presence of virulent or nonvirulent organisms, urgency, omentoplasty and follow-up.

RESULTS. Twenty-one studies and 1.052 patients were included. For TR and PR the rates of early mortality and reinfection were $16.8 \%$ and $10.5 \%, 11 \%$ and $27 \%$ respectively. For TR urgency and male gender were associated with increased rate of early mortality and male gender, PDF and virulent organisms were associated with increased risk of reinfection. For PR no statistical correlation was analyzable except for PDF with increased risk of reinfection.

CONCLUSION. Early mortality rates are higher for TR and reinfection rates are higher for PR. For TR early mortality increases in urgent cases and it is suggested that alternative option must be discussed, reinfection decreases in the presence of nonvirulent organisms and TR seems optimal. For TR and PR reinfection increases in presence of PDF and alternative technique may be more appropriate.

Keywords: - meta-analysis- outcomes of in situ reconstruction- infected aortic grafttotal or partial removal. 


\section{INTRODUCTION}

Aortic graft infection (AGI) is a life-threatening complication that occurs in $1 \%$ to $5 \%$ of patients who undergo conventional abdominal aortic surgery ${ }^{1-4}$,causing major morbidity, mortality, and economic cost ${ }^{5-7}$.The prognosis depends on a multitude of factors including the underlying condition of the patient, urgency, presence of sepsis, virulence of the infecting organism(s), infection linked to prosthetic-duodenal fistula (PDF), and finally the surgical modalities of AGI treatment ${ }^{8-12}$. Contemporary management of $A G I$ includes:

- $\quad$ total resection of the infected graft, with either concomitant extra-anatomic reconstruction (EAR) or in situ reconstruction (ISR) ${ }^{13}$

- $\quad$ partial resection (PR)

In a recent meta-analysis, ISR was associated with a lower occurrence of events than EAR, and these results suggest that ISR may be considered as a first-line treatment ${ }^{14}$. Most authorities agree that total resection (TR) of the infected aortic graft is mandatory for intracavitary AGI ${ }^{15-17}$. However, extensive dissection to achieve total graft excision could disrupt the collateral blood supply and create a problem of pelvic and limb ischaemia ${ }^{18,19}$. Moreover, the total graft removal approach is clearly not feasible in some patients with severe comorbidites or extremely hostile abdomens ${ }^{20}$.

On the other hand, partial graft preservation techniques are becoming increasingly popular as a method to treat established graft infection ${ }^{21-25}$. However, partial resection (PR) varies widely in the series, there is no consensus for assessing the extent of infection on the graft, indications are not clear, and outcomes reported in the series are limited.

Despite a considerable number of publications including total or partial excision of the infected aortic graft there has been no systematic review or meta-analysis to assess the clinical outcomes of ISR associated with the 2 excision modalities. The 
purpose of this meta-analysis was to determine the most appropriate indication for TR or PR of an infected aortic graft in light of the different outcomes after ISR.

\section{Methods}

The present review was conducted in accordance with the Preferred Reporting Items for Systematic Reviews and Meta-Analysis (PRISMA) guidelines ${ }^{26}$. A review protocol can be accessed online in Appendix $A$.

\section{Research Strategy :}

A literature search was performed using MEDLINE and EMBASE, covering all studies published in English between January 1997 and June 2017, as well as recommendations for reporting treatment of aortic graft infection ${ }^{27}$. The medical subject headings (MeSH) used for the search were aortic, graft, and infection. The following key words were also used: Rifampin or Rifampicin-coated polyester grafts, polyester or Dacron, cryopreserved allografts, autogenous veins, Silver-coated polyester, prosthetic-duodenal-fistula, and partial resection (PR), or total resection(TR).

Inclusion and exclusion criteria were defined to determine the selection of clinical studies (detailed online in Appendix B). References from identified studies were also reviewed to ensure that all relevant published papers had been identified. The electronic search was accompanied by a manual search of all the reference lists from the relevant articles.

\section{Study Selection:}

The selected clinical studies included ISR with autogenous veins, cryopreserved allografts and synthetic prostheses that were either standard, Rifampicin bonded or Silver coated polyesters. They also included PDF, (classified as a separate entity ${ }^{27}$ ), and the modality of intervention (emergency or planned) for assessment in the meta-regression analysis. Special attention was paid to the extent of the resection: total resection (TR) or partial resection (PR) of the infected aortic graft.

With no prior knowledge of the authors or the outcomes of the selected publications, two reviewers used a standardized scoring system to rate the clinical 
and methodological quality of each study ${ }^{28}$ (detailed online in Appendix C). Studies that did not - rate above the 18/28 quality score threshold were excluded from the meta-analysis. All studies that did meet the inclusion and exclusion criteria were found to have a quality score above this threshold. These assigned quality scores were not used to compare the results of individuals studies.

\section{Data Extraction:}

When the available written information was insufficient for the meta-analysis, strenuous efforts were made to contact the principal investigator and obtain the necessary information in order to reduce the effect of publication bias.

Two reviewers independently extracted the data from each selected publication. Inter-rater reliability was high-The primary outcome measures were early $(<1$ year) and late mortality ( $>1$ year) $)^{12}$. Additional data was extracted regarding rates of amputation and reinfection of the in situ graft".

\section{Statistical Analysis:}

The purpose of this meta-analysis was to statistically compare the estimated mean occurrence rate of the following events: early (operative) /late mortality, amputation and reinfection. These rates were pooled from studies including the following variables: age, male prevalence, emergency operation, PDF, omentoplasty, microbiology data and follow-up.

We used Comprehensive Meta-Analysis software to carry out this project. With this software, we estimated the pooled values of the parameters (estimation of frequency in meta-analysis) as well as their confidence intervals.

We estimated the heterogeneity using Cochran's $Q$ test with the point estimate of $I^{2}$. Heterogeneity was visually analyzed with a Forestplot, and quantified using Cochran's $Q$ test with the point estimate of $\mathrm{I}^{2}$. If heterogeneity was present ( $Q$ statistic at $5 \%$, and $\mathrm{I}^{2}$ high), we took it into account using the DerSimonian and Laird random-effects method, and if not, using the fixed-effects method. 
As there were no randomized trials, when we compared 2 groups, we used a percentage comparison test between the 2 independent groups (chi-squared test). We then researched the publication bias using the Egger method and the trim and fill method. With the latter, we reassessed the results and their confidence interval, taking into account potential missing studies belonging to the analyzed pool. Since the percentage tests generally concerned more than 2 modalities, we used the chisquared test to compare one level with the other levels. When appropriate, correction for multiple comparisons was performed for subgroup analysis.

Meta-régressions were carried out to estimate the heterogeneity effects according to confounding variables, as defined: patient age (above the mean age, patients were defined as older), male prevalence, emergency ISR, presence of PDF, virulent infectious organisms (ie, Staphylococcus aureus, Enterobacteriaceae, beta-hemolytic Streptococcus, Pseudomonas) ${ }^{29}$, non-virulent infectious organisms (ie, commensal organisms or negative bacteriological cultures) ${ }^{29}$, omentoplasty and follow-up. We performed meta-regressions when the number of studies was higher than or equal to 3. The outcome of these methods enabled us to discuss the final results and justify our propositions.

Besides the meta-analysis software, we used the SAS software version 9.3 at the University Institute of Clinical Research of Montpellier (UPRES 2415 Team. Aide à la décision médicale personnalisée-Personalized support for therapeutic decision).

\section{Results}

A total of 2,327 unique articles were identified, 382 of which were retrievied for analysis. Inclusion/exclusion criteria were met by 31 publications. Ten articles were excluded using a standard scoring system. Twenty-one studies and 1,052 patients, were included in this meta-analysis (detailed online in Appendix D). They were classified according to the extent of infection of the aortic graft (either as P0 graft infection of cavitary graft, eg. aorto-aortic or aorto- bi-iliac graft, or as P2 graft infection of extra-cavitary graft, eg. infection of extra-cavitary portion of the graft whose origin is cavitary, eg. aorto-bifemoral graft) ${ }^{27}$, and the extent of resection of the infected aortic graft: total resection( TR), or partial resection (PR). 
Nearly all the studies used in this meta-analysis were retrospective and observational. As expected, none of the studies were randomized control trials. The primary characteristics of clinical studies and covariates used in this meta-analysis are detailed online in Appendix $E^{8-11,24,25,30-44}$.

The mean number of patients across all studies was 50 ( range: 2-220). There were 887 TR (84 \%), and 165 PR (16\%) with 6 studies (382 patients) combining TR (259 patients) and PR (123 patients) ${ }^{10,31,34,36,40,42}, 11$ studies with solely TR (628 patients) $8,9,11,30,32,33,35,37,41,43,44$, and 4 studies with solely PR (42 patients) ${ }^{24,25,38,39}$.

The mean patient age for the entire series was 66.1 years (range 29-91 years); the mean age of patients with TR and PR was 65.1 years (range 29-86 years), and 67.7 years (range 43-91 years) respectively ( $P=N S$ ).

Different comorbidities and risk factors, detailed online in Appendix $E$, were not available in all the studies, and therefore statistical comparison between the outcomes of the patients with TR and PR must be interpreted with caution.

\section{$1^{\circ}$ Outcomes after total resection:}

a) Early mortality:

Separate sets of data were available for 13 studies (642 patients).After correction of bias the adjusted early mortality rate was $16.8 \%$; $95 \% \mathrm{Cl}: 11.8 \%-22.6 \%$, (Table $1 \mathrm{~A}$ ). In a meta-regression analysis (Table $1 B$ ) urgency of the intervention $(P=.001)$, male prevalence $(P<.0001)$ and omentoplasty $(P<.0001)$ were associated with increased risk of - early mortality (Figure 1A, 1B, 1C).

b) Late mortality:

Separate sets of data were available for 11 studies (585 patients). After correction of bias, the adjusted late mortality rate was $28.5 \%$; $95 \% \mathrm{Cl}: 25 \%-32 \%$, (Table $1 \mathrm{~A}$ ).In a meta-regression analysis (Table $1 \mathrm{~B})$, only omentoplasty $(\mathrm{P}=.006)$ was associated with decreased risk of late mortality (Figure 2).

c) Reinfection:

Separate sets of data were available for 16 studies (808 patients). After correction of bias the adjusted reinfection rate was $11 \%$; $95 \% \mathrm{Cl}$ : $6 \%-19 \%$ (Table $1 \mathrm{~A})$.In a meta- 
regression analysis (Table1C), patient age $(P<.0001)$, presence of PDF $(P=.002)$, and virulent infectious organisms $(P=.001)$ - were associated with increased risk of reinfection (Figure $3 A, B, C)$, whereas nonvirulent infectious organisms $(P<.0001)$ was associated with decreased risk of reinfection (Figure 3D).

d) Amputation :

Separate sets of data were available for 14 studies (660 patients). After correction of bias, the adjusted amputation rate: $8.1 \% ; 95 \% \mathrm{Cl}$ : $6 \%-11 \%$, (Table $1 \mathrm{~A})$. In a metaregression analysis, (Table1C), presence of PDF $(P=.042)$, and length of follow-up ( $P$ $=.006$ ), were both associated with increased risk of amputation (Figure 4 ), whereas male prevalence was associated with decreased risk of amputation $(P=.026)$.

\section{$2^{\circ}$ Outcomes after partial resection:}

a) Early mortality:

Separate sets of data were available for 6 studies (68 patients). After correction of bias, the adjusted operative mortality rate: $10.5 \%$; $95 \% \mathrm{Cl}: 4 \%-22 \%$, (Table 2 ). In a meta-regression analysis (Table 1B), there was no analyzable correlation between the variables considered $(P>.05)$.

b) Late mortality:

Separate sets of data were available for 5 studies (49 patients). After correction of bias, the adjusted late mortality rate: $18 \% ; 95 \% \mathrm{Cl}$ : $9 \%-32 \%$, (Table 2 ).In a metaregression analysis (Table 1B), there was no analyzable correlation between the variables considered $(P>.05)$.

c) Reinfection:

Separate sets of data were available for 10 studies (165 patients). After correction of bias, the adjusted reinfection rate: $27 \%$; $95 \% \mathrm{Cl}: 12 \%-50 \%$, (Table 2 ). In a metaregression analysis (Table $1 \mathrm{C})$, only the presence of PDF $(\mathrm{P}=.01)$ was associated with increased risk of reinfection (Figure 5).

d) Amputation: 
Separate sets of data were available for 7 studies (74 patients). After correction of bias the adjusted amputation rate: $15.4 \%$; $95 \% \mathrm{Cl}: 8 \%-29 \%$, (Table 2 ). In a metaregression analysis (Table $1 \mathrm{C}$ ), there was no analyzable correlation with the variables considered $(P>.05)$.

\section{Discussion}

Treatment for AGI is still very much under discussion, and optimal management of patients is still an unsolved challenge. Miller ${ }^{45}$ was one of the first to introduce the concept of partial aortic graft removal accomplished with a $13 \%$ early mortality rate, $33 \%$ persistent infection and thereby challenged the paradigm of entire aortic graft excision .

The results from the present meta-analysis are summarized in Table $1 \mathrm{~A}, 2$ : early/late mortality, reinfection and amputation rates for TR and PR are $16.8 \%$ and $10.5 \%, 28.5 \%$ and $18 \%, 11 \%$ and $27 \%$, and $8.1 \%$ and $15.4 \%$ respectively . They are in keeping with previously published reviews/meta-analyses ${ }^{12-14}$. However, statistical comparison with TR and PR must be weighted with the limitations of meta-analysis and interpreted with caution (see below).

Perhaps the most difficult aspect of managing AGI is deciding on the appropriate treatment for any given patient :

- regarding the manifestations of the patients concerned, most authorities agree that TR is mandatory for intra-cavitary AGI in patients with favorable conditions ${ }^{13,15-}$ 17 , but there is an increasing number of patients with severe comorbidities and for whom this approach would be inappropriate and even ill-advised, resulting in a prohibitive mortality rate. Thus, it was suggested that the premise of a more limited aortic reconstruction might benefit the patient by avoiding aortic clampage, reducing physiological stress, and limiting the extent of dissection needed to excise the entire graft.

- on the other hand, concerning the extent of AGI, numerous authors ${ }^{38-41,43-45}$ agree that for pangraft infection, TR is the most advisable, and when AGI is localized, PR appears recommendable ${ }^{24,25}$. However there are numerous other clinical scenarios 
where optimal treatment is not clearly defined. To make the most appropriate decision, evaluation of outcomes in each situation may be helpful.

\section{Early and late mortality:}

In the meta-analysis, operative mortality rates were higher for TR than PR, with $16.8 \%$ and $10.5 \%$ respectively (Table $1 \mathrm{~A}, 2$ ).

In the literature review, urgency of the intervention for AGI is one of the most important determinants of in-hospital mortality $9,12,18,40,46-52$. Not surprisingly, in the meta-regression analysis (Table 1B), urgency had a negative correlation with operative mortality for TR (Figure 1A), but no correlation was analyzable for PR. Hence, in order to lower operative mortality in an emergency situation, there may be fewer surgical options available for patients who cannot be stabilized long enough to select the most appropriate surgical option. In this difficult situation, it is suggested that endovascular bridge therapy might be the only realistic option $13,-53-56$.

Male gender was prevalent in this study (online Appendix E). In the meta-regression (Table 1B), male gender had a negative correlation with operative mortality for TR (Figure 1B), but no correlation was analyzable for PR. In the literature female gender was considered as an independent predictor for operative mortality ${ }^{18}$. In the results of the present study, the higher operative mortality observed in males is probably related to the epidemiology of cardiovascular disease and the prevalence of cardiovascular risks in males ${ }^{57}$.

In 1987, Walker was one of the first to propose omentoplasty for protection against reinfection ${ }^{58}$, and its benefits were confirmed by numerous studies for both TR and PR 9,11,13,18, 37,54 In the meta-regression(Table 1B), the negative correlation between omentoplasty and operative mortality is not clear (Figure 1C), because omentoplasty is considered a safe procedure, associated with a moderate number of post-operative complications ${ }^{59}$. In our opinion, such discrepancy could only be explained by the differences amongst patients undergoing surgical procedures, particulary any underlying diseases.

In the meta-analysis, late mortality rates were higher for TR than for PR with $28.5 \%$ and $18 \%$ respectively (Table $1 \mathrm{~A}, 2$ ), and in the meta-regression, omentoplasty had a 
positive correlation with late mortality for TR (Figure 2), although no correlation was analyzable for PR (Table 1B). Such benefits for patients with omentoplasty are probably linked to the decrease in late infectious mortality caused by dehiscence of anastomosis and fatal hemorrhage.

\section{Reinfection and amputation:}

In the results of the meta-analysis reinfection rates were higher for PR than for TR, with $27 \%$ and $11 \%$ respectively (Table $1 \mathrm{~A}, 2$ ). The literature ${ }^{60-62}$ supports this idea that complete graft excision minimizes the risk of reinfection and Ricotta reported persistent or recurrent infection in $25 \%$ of the grafts treated with PR but no reinfection after $\mathrm{TR}^{62}$.

In the literature there is a link between reinfection and patient age ${ }^{10,11,63}$, presence of PDF ${ }^{10,12,18,47,48,64}$ and virulent ${ }^{10,25,32,43,48,65-67}$ or nonvirulent ${ }^{64,68-70}$-infecting organisms. In the meta-regression (Table 1C), age and virulent organisms had a negative correlation with reinfection for TR (Figure $3 \mathrm{~A}, \mathrm{C}$ ), nonvirulent organisms had a positive correlation for TR (Figure 3D), and PDF had a negative correlation for

TR and PR (Figure 3B, Figure 5). The results of the present study suggest that in

order to lower reinfection rates in the presence of nonvirulent organisms, TR appears optimal. In the presence of PDF, neither TR nor PR were advisable before in

situ reconstruction. It was suggested that extra-anatomic bypass still has an important role ${ }^{18,71}$, and staged endovascular approach with early conversion to in situ repair with a vein or prosthetic graft with omental wrapping may achieve the best results ${ }^{55}$. For older patients or in the presence of virulent organisms fewer surgical options may have been available because TR was not recommendable and

PR had no analyzable correlation. Thus, for older patients or in the presence of virulent organisms, if the patient is hemodynamically stable and not septic, it has

been suggested that percutaneous drainage of peri-aortic abcesses or fluid collections, and intensive treatment of infection or comorbidities could be done before more extensive operation ${ }^{72}$, and consequently, extra-anatomic reconstruction ${ }^{18}$ or in situ reconstruction with femoral veins ${ }^{12,14}$ may be the most appropriate .

Omentoplasty was recommended to lower reinfection rates ${ }^{9,11,13,18,24,31,37,58}$. Unfortunately, in the present study, no correlation was analyzable. However, 
omentoplasty is not always feasible, for instance in the event of extra-cavitary graft infection or a retroperitoneal approach ${ }^{24,25}$.

In the results of the meta-analysis, amputation rates were higher for PR than for TR, with $15.4 \%$ and $8.1 \%$ respectively (Table $1 \mathrm{~A}, 2$ ). Unsurprisingly, in the metaregression (Table $1 \mathrm{C}$ ), amongst the population of patients with vascular risks, followup had a negative correlation with amputation for TR (Figure 4), and the results for PR were not analyzable. The nature of the conduit was probably the major factor 12,14 .

This meta-analysis suggests indications for PR or TR of infected aortic graft according to patient manifestations and the bacteriologic data, but unfortunately it could not provide any recommendations as to how to make future decisions regarding patient treatment because this study is a meta-analysis of retrospective studies, not prospective, nor randomized. Moreover, observational studies used in this metaanalysis were difficult to analyze and interpret because the discrepancy between patient numbers in each group (887 TR vs 165 PR) caused a problem for statistical comparison. This drawback was owing to the lack of standardized indications for TR or PR in the series, and not this meta-analysis.

Finally, the main finding of this study was the reduced post-operative mortality with $P R$ at the price of the increased late reinfection. Therefore, management of AGI is clearly not easy, and is still under discussion. In order to define an optimal strategy, decisions must be tailored following the input of all clinicians involved, i.e. vascular surgeon, microbiologist/infectious disease physician, interventional and imagist radiologist and others, taking due cognizance of the individual patient's condition and state ${ }^{13,73-77}$. Moreover, operative flexibility is required should unexpected difficulties arise during the intervention.

\section{Study Limitations:}

Some limitations, mostly related to potential bias, are encountered in this metaanalysis: 


\section{- Studies selection bias:}

The selection process for publications, notably the manner in which we pooled the data from individual studies, may be a source of bias. Inclusion/exclusion criteria were defined in attempt to limit selection bias. For example, infected aortic aneurysms were excluded because, etiology, bacteriology and treatment results are different from those of $A G I{ }^{13,48,78}$, and the series combining total and partial removal of infected aortic grafts were excluded if the results were not differentiated. On the other hand, our inclusion/exclusion criteria may have biased the outcome of the meta-analysis. For example, we only considered clinical studies whose results were reported in the English language. Hence, results extracted from medical journals in languages other than English were excluded. We believe that publication bias was limited by the use of the Funnel plots and complementarity validation tests.

\section{- Outcome reporting bias:}

Nearly all studies analyzed were retrospective and observational. Consequently, there are problems concerning inter-study heterogeneity and selection bias ${ }^{79}$ despite reasonable efforts to perform tests of heterogeneity (Table $1 \mathrm{~A}, 2$ ):

- it is possible that some significant medical considerations were not available in a number of studies. These include, cigarette smoking (not reported in the majority of the series) which is associated with increased surgical risk of site infection ${ }^{80}$, time to clinical presentation of the infection divided into early and late presentation (<3months or after 3 months $)^{23}$, infection presented, and specific informations on the pre-operative status of the patients: coronary heart disease, HTA, diabetes mellitus, renal failure, chronic obstructive pulmonary disease, ASA score, immunosuppression, history of neoplasm, body mass index ${ }^{-81}$, anatomic considerations (hostile abdomens, poor pelvic collateral blood supply, tight attachment of the infected graft to the iliac vessels and the ureter, aortic graft involving the renal or visceral aortic segment), and so forth. These risk of bias across the studies create reservations regarding the comparison of outcomes after TR and $\mathrm{PR}^{27}$. For example, partial graft removal of the infected aortic graft was probably performed in a group of patients who have a more significant operative risk compared to those who underwent total graft removal, but these differences, 
despite reasonable efforts, cannot be shown in the different studies. This drawback concerns the reported studies themselves and not this meta-analysis.

- there is also a possibility that some specific aspects of treatment were not available, yet had an impact on perioperative outcomes: drainage of peri-prosthetic abscesses, use of sartorius flap ${ }^{21}$ or Vacuum- assisted closure device, the experience of each center (number of patients treated per year for AGI), lack of consensus concerning the nature and duration of postoperative antibiotherapy ${ }^{82}$, and so forth.

As a result, the eligible sample size for analysis was considerably reduced. However, this drawback concerns the reported studies themselves and not this meta-analysis.

- Limits of meta-regression:

The associations derived from meta-regression are observational and have a weaker interpretation than the causal relationships derived from randomized comparisons. Data dredging is the main pitfall in reaching reliable conclusions from meta-regression, and pre-specification of covariates is heightened. Therefore, special attention was paid to selected relevant covariates in this study. For instance, the nature of the conduit has an impact on operative outcomes ${ }^{12,14}$, but these differences could not be captured in the present meta-analysis owing to heterogeneity between PR and TR.

\section{Conclusion}

The results of this meta-analysis suggest that operative mortality rates are higher for TR, and reinfection rates are higher for PR .

Operative mortality increases in urgent cases for TR. Hence in order to lower operative mortality in an emergency situation it is suggested that alternative option must be discussed.

Reinfection decreases for TR in the presence of nonvirulent infectious organisms, and in order to lower reinfection TR seems optimal. In the presence of virulent 
organisms and PDF reinfection increases for TR and alternative techniques may be most appropriate.

\section{Acknowledgments}

The authors thank Brigitte Havé, Danielle Sullivan, and Patrick Davignon for technical help and writing assistance. 


\section{References}

1) Svensson LG, Crawford ES, Hess KR, Coselli JS, Safi HJ. Experience with 1509 patients undergoing thoracoabdominal aortic operations. J Vasc Surg. 1993; 17:357370.

2) O'Hara PJ, Hertzer NR, Beven EG, Krajewski LP. Surgical management of infected abdominal aortic grafts: review of a 25-year experience. J Vasc Surg. 1986; 3: 725731.

3) Kuestner LM, Reilly LM, Jizha DL, Ehrenfeld WK, Goldstone J, Stoney RJ. (1995) Secondary aorto-enteric fistula: contemporary outcome with use of extranatomic bypass and infected graft excision. J Vasc Surg. 1995; 21: 184-196.

4) Berger P, Vaartjes I, Moll FL, De Borst GJ, Blankensteijn JD, Bots ML. Cumulative incidence of graft infection after primary prosthetic aortic reconstruction in the endovascular era. Eur J Vasc Endovasc Surg. 2015; 49: 581-585.

5) Darouiche RO. Treatment of infections associated with surgical implants. N Engl J Med. 2004; 350:1422-1429.

6) Tatterton MR, Homer-Vanniasinkam S. Infections in vascular surgery. Injury. 2011; 42(Suppl.5):S35-41.

7) Nevelsteen A, Lacroix H, Suy R. Infrarenal aortic graft infection: in situ aortoiliofemoral reconstruction with the lower extremity deep veins. Eur J Vasc Endovasc Surg. 1997; 14 (Supplement A):88-92.

8) Lavigne JP, Postal A, Kohl P, Limet R. Prosthetic vascular infection complicated or not by prosthetic-duodenal fistula : comparison of treatment with and without cryopreserved allograft (homografts). Eur J Vasc Endovasc Surg. 2003; 25: 416-423.

9) Kieffer E, Gomes D, Chiche L, Fleron MH, Koskas F, Bahnini A. Allograft replacement for aortic graft infection: early and late results in 179 patients. J Vasc Surg. 2004; 39:1009-1017. 
10) Harlander-Locke MP, Harmon LK, Lawrence PF, Oderich GS, McCready RA, Morasch MD, et al, for the Vascular Low-Frequency Disease Consortium.The use of cryopreserved aortoiliac allograft for aortic reconstruction in the United States. J Vasc Surg.2014; 59:669-674.

11) Garot M, Delannoy PY, Meybeck A, Sarraz-Bournet B, d'Elia PV, d'Escrivan T, et al. Intra-abdominal aortic graft infection: prognostic factors associated with inhospital mortality. BMC Infect Diseases. 2014; 14:215-222.

12) O'Connor S, Andrew P, Batt M, Becquemin JP. A systematic review and metaanalysis of treatment for aortic graft infection. J Vasc Surg. 2006; 44:38-45.

13) Wilson WR, Bower TC, Creager MA , Amin-Hanjani S, O'Gara PT, Lockhart PB, et al. Vascular graft infections, mycotic aneurysms, and endovascular infections. A scientific statement from the American Heart Association. Circulation. 2016; 134: e412-e460.

14) Batt M, Feugier P, Camou F, Coffy A, Senneville E, Caillon J, et al. A meta-analysis of outcomes after in situ reconstruction for aortic graft infection. Angiology. 2018; 69: $370-379$

15) Goldstone J, Moore WS. Infection in vascular prostheses: clinical manifestations and surgical management. Am J Surg. 1974; 128:225-233.

16) Jamieson GG, De Weese JA, Rob CG. Infected arterial grafts. Ann Surg. 1975; 181:850-852.

17) Szilagyi DE, Smith RF, Elliott JP, Vranderic MP. Infection in arterial reconstruction with synthetic grafts. Ann Surg. 1972; 176 :321-333.

18) Oderich GS, Bower TC, Hofer Y, Kalra M, Duncan AA, Wilson WW, et al. In situ rifampin-soaked graft with omental coverage and antibiotic suppression are durable with low reinfection rates in patients with aortic graft enteric erosion or fistula. J Vasc Surg. 2011; 53:99-107.

19) Batt M, Hassen-Khodja R, Staccini P, Bariseel H, Declemy S, Le Bas P.The internal iliac arteries do not supply the inferior mesenteric artery. Intern J Angiol. 1998; 7: 165-168. 
20) Calligaro KD, Veith FJ, Yuan JG, Garguilo NJ, Dougherty MJ. Intra-abdominal aortic graft infection: Complete or partial graft preservation in patients at very high risk. J Vasc Surg. 2003; 38:1199-1205.

21) Armstrong PA, Back MR, Bandyk DF, Jonhson BL, Shames ML. Selective application of Sartorius muscle flap and aggressive staged surgical debridement can influence long term outcomes of complex prosthetic graft infection. J Vasc Surg . $2007 ; 46: 71-78$.

22) Fichelle JM, Al Ayoubi A, Cormier F, Couturaud B, Marzelle J, Trevidic $P$, et al. Infections of aortobifemoral prostheses at level of the Scarpa's triangle- Place of local treatments. Acta chir belg. 2007;107:12-24.

23) Lawrence PF. Conservative treatment of aortic graft infection. Semin Vasc Surg. 2011; 24:199-204.

24) Crawford JD, Landry GJ, Moneta GL, Mitchell EL. Outcomes of unilateral graft limb excision for infected aortobifemoral graft limb. J Vasc Surg. 2016; 63:407-413.

25) Simmons $C D$, Ali $A T$, Foteh $K$, Abate $M R$, Smeds $M R$, Clagett $P$. Unilateral inline replacement of infected aortofemoral graft limb with femoral vein. J Vasc Surg. 2017; 65:1121-1129.

26) Moher D, Liberati A, Tetzlaff J, Altman DG. Preferred reporting items for systematic reviews and meta-analyses: the PRISMA statement. Int J Surg. 2010; 8:336-341.

27) Teebken OE, Bisdas T, Assadian O, Ricco JB. Recommendations for reporting treatment of aortic graft infections. Eur J Vasc Endovasc Surg. 2012; 43:174-181.

28) Berman NG, Parker RA. Meta-analysis: neither quick nor easy. BMC Med Res Methodol. 2002 2:10.

29) Osmon DR, Berbari EF, Berendt AR, Lew D, Zimmerli W, Steckelberg JM, et al. Diagnosis and management of prosthetic joint infection: clinical practice guidelines by the Infectious Diseases Society of America. Clin Infect Dis. 2013 ; 56 : e1-e25.

30) Speziale F, Rizzo L, Sbarigia E, Giannoni MF, Massucci M, Maraglino C, et al. Bacterial and clinical criteria relating to the outcome of patients undergoing in situ 
replacement of infected abdominal aortic grafts. Eur J Vasc Endovasc Surg. 1997; 13: 127-133.

31) Young RM, Cherry KJ, Davis PM, Gloviczki P, Bower TC, Panneton JM, et al. The results of in situ prosthetic replacement for infected aortic grafts. Am J Surg. 1999; 178:136-140.

32) Hayes PD, Nasim A, London NJM, Sayers RD, Barrie WW, Bell PRF, et al. In situ replacement of infected aortic grafts with rifampicin-bonded prostheses: The Leicester experience (1992 to 1998 ). J Vasc Surg. 1999; 30 :92-98.

33) Chiesa R, Astore D, Frigerio S, Garriboli L, Piccolo G, Castellano R, et al. Vascular prosthetic graft infection : Epidemiology, bacteriology, pathogenesis and treatment. Acta chir belg. 2002; 102:238-247.

34) Cardozo MA, Frankini AD, Bonamigo TP. Use of superficial femoral vein in the treatment of infected aortoiliofemoral prosthetic grafts. Cardiovasc Surg. 2002; 10: 304-310.

35) Daenens K, Fourneau I, Nevelsteen A.Ten-years experience in autogenous reconstruction with the femoral vein in the treatment of aortofemoral prosthetic infection. Eur J Vasc Endovasc Surg. 2003; 25:240-245.

36) Batt M, Magne JL, Alric P, Muzj A, Ruotolo $C$, Ljungstrom KG, et al. In situ revascularization with silver-coated polyester grafts to treat aortic infection: early and midterm results. J Vasc Surg. 2003; 38:983-989.

37) Gabriel M, Pukacki F, Dzieciuchowicz L, Oszkinis G, Checinski P. Cryopreserved arterial allografts in the treatment of prosthetic graft infections. Eur J Vasc Endovasc Surg. 2004; 27:590-596.

38) Hart JP, Eginton MT, Brown KR, Seabrook GR, Lewis BD, Edmiston CF Jr, et al. Operative strategies in aortic graft infections: is complete graft excision always necessary? Ann Vasc Surg. 2005; 19 :154-160.

39) Mirzaie M, Schmitto JD, Tirilomis T, Fatehpur S, Liakopoulos OJ, Teucher N, et al. Surgical management of vascular graft infection in severely ill patients by partial resection of the infected prosthesis. Eur J Vasc Endovasc Surg. 2007; 33:610-613. 
40) Batt M, Jean-Baptiste E, O'Connor S, Bouillanne PJ, Haudebourg P, HassenKhodja $R$, et al. In-situ revascularisation for patients with aortic graft infection : a single center experience with silver coated polyester grafts. Eur J Vasc Endovasc Surg. 2008; 36:182-188.

41) Chung J, Clagett GP. Neoaortoiliac system ( NAIS) procedure for the treatment of the infected aortic graft. Semin Vasc Surg. 2011; 24:220-226.

42) Batt M, Jean-Baptiste E, O'Connor S, Feugier P, Haulon S. Contemporary management of infrarenal aortic graft infection: early and late results in 82 patients. Vascular. 2012; 20:129-137.

43) Charlton-Ouw KM, Sandhu HK, Huang G, Leake SS, Miller CC III, Estrera AL, et al. Reinfection after resection and revascularization of infected infrarenal abdominal aortic grafts. J Vasc Surg 2014; 59:669-674.

44) Heinola I, Kantonen I, Jaroma $M$, Albäck A, Vikatmaa $P$, Aho $P$, et al. Treatment of aortic prosthesis infections by graft removal and in situ replacement with autologous femoral veins and fascial strengthening. Eur J Vasc Surg. 2016; 51:232239.

45) Miller JH. Partial replacement of an infected arterial graft by a new prosthetic polytetrafluoroethylene segment: A new therapeutic option. J Vasc Surg. 1993; 17: 546-558.

46) Dorigo W, Pulli R, Azas L, Pratesi G, Innocenti AA, Pratesi C. Early and long -term results of conventional surgical treatment of secondary aorto-enteric fistula. Eur J Vasc Endovasc Surg. 2003; 26: 512-518.

47) Batt M, Jean-Baptiste E, O'Connor S, Saint-Lebes B, Feugier P, Patra P, et al. Early and late results of contemporary management of 37 secondary aortoenteric fistulae. Eur J Vasc Endovasc Surg. 2011; 41: 748-757.

48) Touma J, Cochenec F, Parisot J, Fialaire Legendre A, Becquemin JP, et al. In situ reconstruction in native and prosthetic aortic infections using cryopreserved arterial allografts. Eur J Vasc Endovasc Surg. 2014; 48:292-299.

49) Finks JF, Osbome NH, Birkmeyer JD. Trends in hospital volume and operative mortality for high-risk surgery. N Engl J Med. 2011; 364: 2128-2137. 
50) Hoomweg LL, Stom-Versloot MN, Ubbink DT, Legemate MJW, Balm R. Meta analysis on mortality of ruptured abdominal aortic aneurysms. Eur J Vasc Endovasc Surg. 2008; 35:558-570.

51) Yeager RA, Taylor LM, Moneta GL, Edwards JM, Nicoloff AD, McConnell DB, et al. Improved results with conventional management of infrarenal aortic infection. J Vasc Surg. 1999; 30:76-83.

52) Joo H-C, Lee S-H, Chang B-C, Lee S, Yoo K-J, Youn Y-N. Late open conversion after endovascular abdominal aortic repair: a 20 year experience. J Cardio Cardiovasc Surg 2018 Mar 12- Minerva Medica, DOI: 10.23736/S0021-9509.18. 10173-X

53) Bergqvist D, Björck M. Secondary arterioenteric fistulisation- A systematic literature analysis. Eur J Vasc Endovasc Surg. 2009; 37: 31-42.

54) Danneels MIL, Verhagen HJM, Teijink JAW, Cuypers P, Nevelsteen A, Vermassen FEG. Endovascular repair for aorto-enteric fistula: A bridge too far or a bridge to surgery? Eur J Vasc Endovasc Surg. 2006; 32: 27-33.

55) Kakkos S, Bicknell CD, Tsolakis IA, Bergqvist D, the Hellenic Co-operative Group on Aortic Surgery. Management of secondary aorto-enteric and other abdominal arterio-enteric fistulas: A review and pooled data analysis. Eur J Vasc Endovasc Surg. 2016; 52:770-786

56) Katsargyris A, Marques DE MARINO P, VERHOEVEN E. Graft design and selection of fenestrations vs branches for renal and mesenteric incorporation in endovascular treatment of pararenal and thoracoabdominal aortic aneurysms. J Cardio Vasc Surg 2018 Jun 26- Minerva Medica, DOI: 10.23736/S0021-9509.18.10642-2.

57) Mahmood SS, Levy D, Vasan RS, Wang TJ.The Framingham Heart Study and the epidemiology of cardiovascular disease: a historical perspective. Lancet. 2014; 383:999-1008.

58) Walker EW, Cooley DA, Duncan JM, Hallman GL, Ott DA, Reul GJ. The management of aortoduodenal fistula by in situ replacement of the infected abdominal aortic graft. Ann Surg. 1987; 205:727-732. 
59) van Garderen JA, Wiggers T, van Geel AW. Complications of the pedicled omentoplasty. Netherl J Surg 1991; 43: 171-174.

60) Debus ES, Diener H. Reconstructions following graft infectin: An unsolved challenge. Eur J Vasc Endovasc Surg. 2017; 53: 151-152

61) Ten Raa $S$, Van Sambeek RHM, Hagenaars T, Van Hurk H. Management of aortic graft infection. J Cardiovasc Surg 2002; 43: 209-215.

62) Ricotta JJ, Faggioli GL, Stella A, Curl GR, Peer R, Upson J, et al.Total excision and extra-anatomic bypass for aortc graft infection. Am J Surg. 1991; 162:145-149.

63) Treska V, Houdek K, Vachtova M, Smid D, Kormunda S. Management of the prosthetic vascular graft infections- the influence of predictive factors on treatment results. Bratisl Lek Listy. 2008; 109: 544-550.

64) Armstrong PA, Back MR, Wilson JS, Shames ML, Johnson BL, Shames ML. Improved outcomes in the recent management of secondary aortoenteric fistula. J Vasc Surg. 2005; 42:660-666

65) Geary KJ, Tomkiewicz ZM, Harrison HN, Fiore WM, Geary JE, Green RM, et al. Differantial effects of a gram-negative and a gram positive infection on autogenous and prosthetic grafts. J Vasc Surg. 1990; 11:339-347.

66) Naylor AR, Hayes PD, Darke $S$ on behalf of the Joint Vascular Research Group A prospective audit of complex wound and graft infections in Great Britain and Ireland: the emergence of MRSA. Eur J Vasc Endovasc Surg. 2001; 21:289-294.

67) Williams IM, Milling MAP, Shandall AA. Vascularised muscular flaps and arterial graft infection in the groin. Eur J Vasc Endovasc Surg 2003; 25:390-395.

68) Bandyk DF, Novotney ML, Johnson BL, Back MR, Roth SR. Use of rifampicinsoaked gelatin-sealed polyester grafts for in situ treatment of primary aortic and vascular prosthetic infections. J Surg Res. 2001; 95 : 44-49.

69) Becquemin JP, Qvarford P, Kron J, Cavillon A, Desgranges P, Allaire E, et al. Aortic graft infection : Is there a place for partial graft removal? Eur J Vasc Surg. 1997;14 (Supplement A): 53-58. 
70) Bandyk DF, Bergamini TM, Kinney EW, Seabrook GR, Towne JB. In situ replacement of vascular prostheses infected by bacterial biofilms. J Vasc Surg. 1991; 13: 575-583.

71) Boyle JR. Superficial femoral vein is superior to cryopreserved allografts for in situ aortic reconstruction. Eur J Vasc Endovasc Surg. 2014; 48:300.

72) Oderich G, Bower TC, Cherry KJ, Panneton LM, Sullivan TM, Noel AA, et al.Evolution from axillofemoral to in situ prosthetic reconstruction of aortic graft infections at a single center. J Vasc Surg. 2006; 43:1166-1174.

73) Fitzgerald SF, Kelly C, Humphreys H. Diagnosis and treatment of prosthetic aortic graft infections: confusion and inconsistency in the absence of evidence or consensus. J Antimicrob Chemother. 2005; 56:996-999.

74) Lyons OTA, Baguneid M, Barwick TD, Bell RE, Foster N, Homer-Vanniasinkam, et al. Diagnosis of aortic graft infection: A case definition by the management of aortic graft infection collaboration (MAGIC). Eur J Vasc Endovasc Surg. 2016; 52:758-763.

75) Rawson TM, Gill D. The role of the multidisciplinary team in decision making for vascular graft infection. J Vasc Surg. 2015; 62:1686.

76) Leroy O, Meybeck A, Sarraz-Bournet B, d'Elia P, Legout L. Vascular graft infections. Infect Dis. 2012; 25:154-158

77) Nurok M, Gewertz B. Interdisciplinary disease-based peer review: moving quality assurance into the future. JAMA. 2018; Surg 153 : 3-4.

78) Sörelius K, Mani K, Björck M, Sedivy P, Wahlgren CM, Taylor $P$, et al. Endovascular treatment of mycotic aneurysms: a European multicenter study. Circulation. 2014; 130: 2136-2142.

79) Petitti DB. Approaches to heterogeneity in meta-analysis. Statistic. 2001; 20: 3625-3633.

80) Nolan MB, Martin DP, Thompson R. Association between smoking status, preoperative exhaled carbon monoxide levels, and postoperative surgical site infection in patients undergoing elective surgery. JAMA Surg. 2017; 152:47-483. 
81) Deyo RA, Cherkin DC, Ciol MA. Adapting a clinical comorbidity index for use with ICD-9-CM administrative databases. J Clin Epidemiol. 1992; 45:613-619.

82) Revest M, Camou F, Senneville E, Caillon J, Laurent F, Calvet B, et al. Medical treatment of prosthetic vascular graft infections : Review of the literature and proposals of a working group. Int J Antimicrob Agents. 2015; 46:254-262. 


\section{Legends of Tables and Figures}

Table I: Meta-Analysis and Heterogeneity Tests of the Results for Total Resection.

Table II: Meta-Regression Analysis of the Risk of Operative and Late Mortality According to Male gender, Omentoplasty and Emergency.

TR: total resection; PR: partial resection.

Table III: Meta-Regression Analysis of the Risk of Reinfection and Amputation According to Age, PDF,Virulent or Nonvirulent Infecting Organisms, Follow-up and Male gender.

TR: Total Resection; PR: Partial Resection, PDF: prosthetic-duodenal fistula, \% male : male gender.

Table IV: Meta-Analysis and Heterogeneity Tests of the Results for Partial Resection.

Figure 1A: Meta-regression plot of emergency against early mortality for total resection (10 studies, $\left.\mathrm{P}=.001, \mathrm{Tau}^{2}=.10\right)$.

Figure 1B: Meta-regression plot of presence of male gendre against early mortality for total resection (10 studies, $\mathrm{P}=0, \mathrm{Tau}^{2}=.144$ ).

Figure 1C: Meta-regression plot of omentoplasty against early mortality for total resection (3studies, $\mathrm{P}=0, \mathrm{Tau}^{2}=.054$ ).

Figure 2: Meta-regression plot of omentoplasty against late mortality for total resection (3 studies, $\left.\mathrm{P}=.006, \mathrm{Tau}^{2}=0\right)$.

Figure 3A: Meta-regression plot of age against reinfection for total resection (11 studies, $P=0$, $\mathrm{Tau}^{2}=.75$ ).

Figure 3B: Meta-regression plot of presence of prosthetic-duodenal fistula against reinfection for total resection (11 studies, $\mathrm{P}=.002, \mathrm{Tau}^{2}=.85$ )

Figure 3C: Meta-regression plot of virulent infectious organisms against reinfection for total resection (11studies, $\mathrm{P}=.001, \mathrm{Tau}^{2}=1.24$ ).

Figure 3D: Meta-regression plot of nonvirulent infectious organisms against reinfection for total resection (10 studies, $\mathrm{P}=0, \mathrm{Tau}^{2}=.33$ ).

Figure 3D: Meta-regression plot of presence of prosthetic-duodenal fistula against reinfection for total resection (11 studies, $\mathrm{P}=.002, \mathrm{Tau}^{2}=.85$ )

Figure 4: Meta-regression plot of follow-up against amputation for total resection (11 studies, $\mathrm{P}=$ $\left..006, \mathrm{Tau}^{2}=.15\right)$. 
Figure 5: Meta-regression plot of prosthetic-duodenal fistula against reinfection for partial resection (4 studies, $\mathrm{P}=.01, \mathrm{Tau}^{2}=0$ ).

\begin{tabular}{|c|c|c|c|c|c|c|}
\hline & $\begin{array}{l}\text { No of } \\
\text { trials } \\
\text { analysis }\end{array}$ & $\begin{array}{c}\mathrm{I}^{2} \\
\text { statistic }\end{array}$ & $\begin{array}{c}\mathrm{P} \text { for } \\
\text { heterogeneity }\end{array}$ & $\begin{array}{l}\text { Method (fixed } \\
\text { or Random- } \\
\text { effects Model) }\end{array}$ & Event Rate & $\begin{array}{l}\text { IC Event } \\
\text { Rate }\end{array}$ \\
\hline $\begin{array}{l}\text { Random model if heterogeneity test is } \\
\text { significant or fixed model if not } \\
\text { - } \quad \text { Operative mortality }\end{array}$ & 13 & 61.3 & 0.002 & Random & 0.162 & $0.113-0.226$ \\
\hline - Reinfection & 16 & 69.7 & 0 & Random & 0.064 & $0.034-0.117$ \\
\hline - Amputation & 14 & 29.7 & 0.14 & Fixed & 0.068 & $0.048-0.095$ \\
\hline - $\quad$ Late mortality & 11 & 37.4 & 0.1 & Fixed & 0.279 & $0.243-0.319$ \\
\hline \multicolumn{7}{|l|}{$\begin{array}{l}\text { Event rates after corrections of } \\
\text { selection bias (Dural and test is trim } \\
\text { and fill) }\end{array}$} \\
\hline - Operative mortality & & & & & 0.168 & $0.118-0.226$ \\
\hline - $\quad$ Reinfection & & & & & 0.110 & $0.06-0.19$ \\
\hline - Amputation & & & & & 0.081 & $0.06-0.11$ \\
\hline - $\quad$ Late mortality & & & & & 0.285 & $0.250-0.320$ \\
\hline
\end{tabular}

Table - I 


\begin{tabular}{|c|c|c|c|c|c|c|c|}
\hline Event & Variables & group & $\begin{array}{l}\text { Study } \\
\text { N }\end{array}$ & Slope & Slope $95 \%$ IC & $p$-value & $\mathrm{T}^{2}$ \\
\hline & \multirow{2}{*}{$\%$ male } & TR & 10 & 0.04 & $-0.02-0.06$ & 0 & 0.144 \\
\hline & & PR & 3 & 0.06 & $-0.05-0.17$ & 0.27 & 0 \\
\hline & \multirow{2}{*}{ Omentoplasty } & TR & 3 & 0.05 & $0.02-0.08$ & 0 & 0.054 \\
\hline & & PR & No corr & ion anc & & & \\
\hline \multirow{3}{*}{$\begin{array}{l}\text { Operative } \\
\text { Mortality }\end{array}$} & & TR & 10 & 0.04 & $0.02-0.06$ & 0.001 & 0.10 \\
\hline & & PR & \multicolumn{3}{|c|}{ No correlation analyzable } & & \\
\hline & & TR & 3 & -0.09 & $-0.16-(-0.03)$ & 0.006 & 0 \\
\hline $\begin{array}{l}\text { Late } \\
\text { Mortality }\end{array}$ & & PR & \multicolumn{3}{|c|}{ No correlation analyzable } & & \\
\hline
\end{tabular}

Table II 


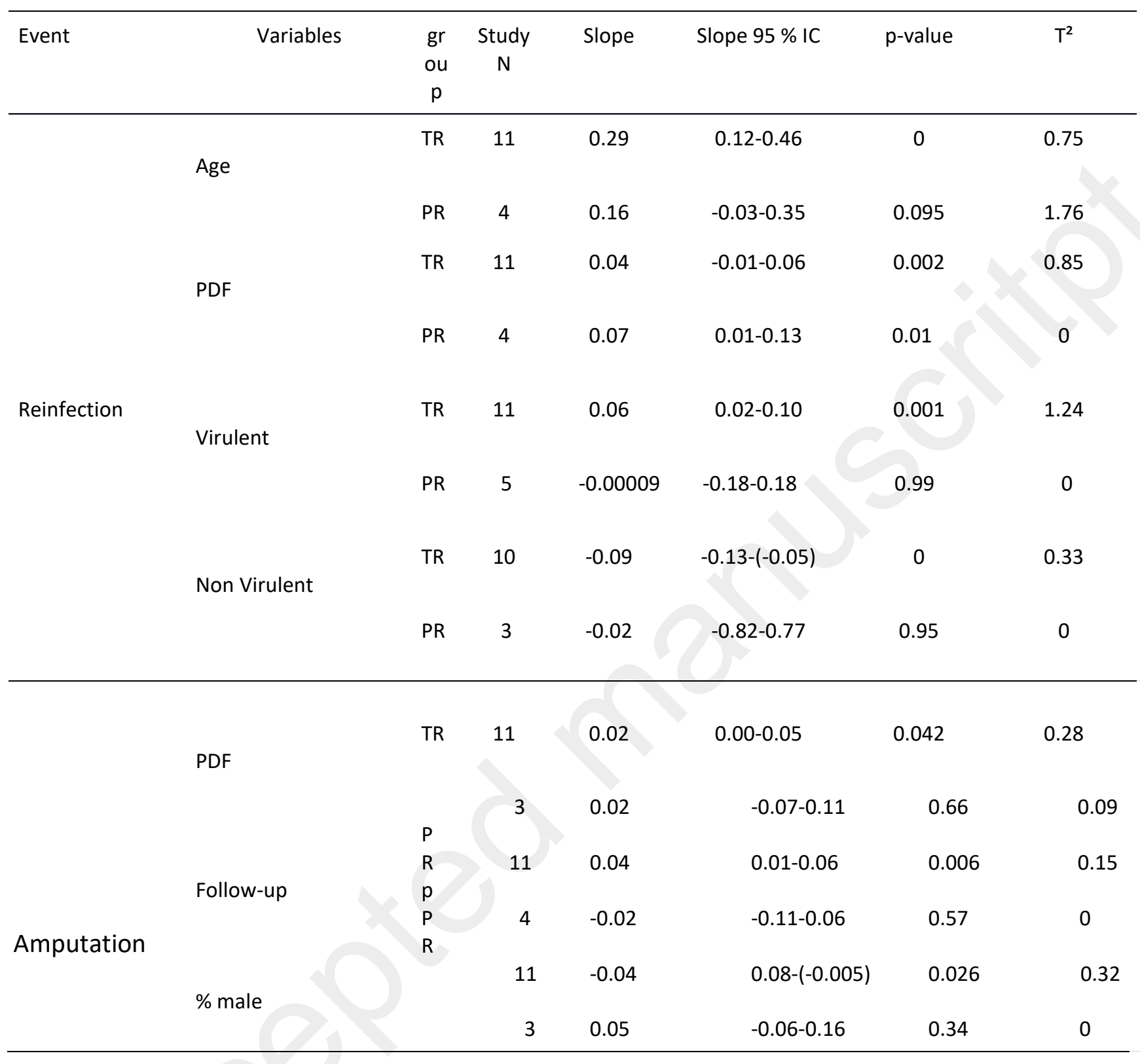

Table III 


\begin{tabular}{|c|c|c|c|c|c|c|}
\hline & $\begin{array}{l}\text { No of } \\
\text { trials } \\
\text { analysis }\end{array}$ & $\begin{array}{c}1^{2} \\
\text { statistic }\end{array}$ & $\begin{array}{c}\mathrm{P} \text { for } \\
\text { heterogeneity }\end{array}$ & $\begin{array}{l}\text { Method (fixed } \\
\text { or Random- } \\
\text { effects Model) }\end{array}$ & Event Rate & $\begin{array}{l}\text { IC Event } \\
\text { Rate }\end{array}$ \\
\hline $\begin{array}{l}\text { Random model if heterogeneity test is } \\
\text { significant or fixed model if not }\end{array}$ & 6 & 0 & 0.8 & Fixed & 0.073 & $0.027-0.18$ \\
\hline - Operative mortality & & & 0001 & Bandom & 0189 & $0081-0383$ \\
\hline $\begin{array}{ll}- & \text { Reinfection } \\
- & \text { Amputation }\end{array}$ & $\begin{array}{c}10 \\
7\end{array}$ & $\begin{array}{c}69.1 \\
0\end{array}$ & $\begin{array}{c}0.001 \\
0.67\end{array}$ & $\begin{array}{l}\text { Random } \\
\text { Fixed }\end{array}$ & $\begin{array}{l}0.189 \\
0.095\end{array}$ & $0.041-0.206$ \\
\hline - Late mortality & 5 & 0 & 0.64 & Fixed & 0.162 & $0.079-0.305$ \\
\hline $\begin{array}{l}\text { Event rates after corrections of selection } \\
\text { bias (Dural and test is trim and fill) }\end{array}$ & & & & & 0.105 & $0.04-0.22$ \\
\hline - Operative mortality & & & & & & \\
\hline - Reinfection & & & & & 0.27 & $0.12-0.50$ \\
\hline - Amputation & & & & & 0.154 & $0.08-0.29$ \\
\hline Late mortality & & & & & 0.18 & $0.09-0.32$ \\
\hline
\end{tabular}

Table IV 


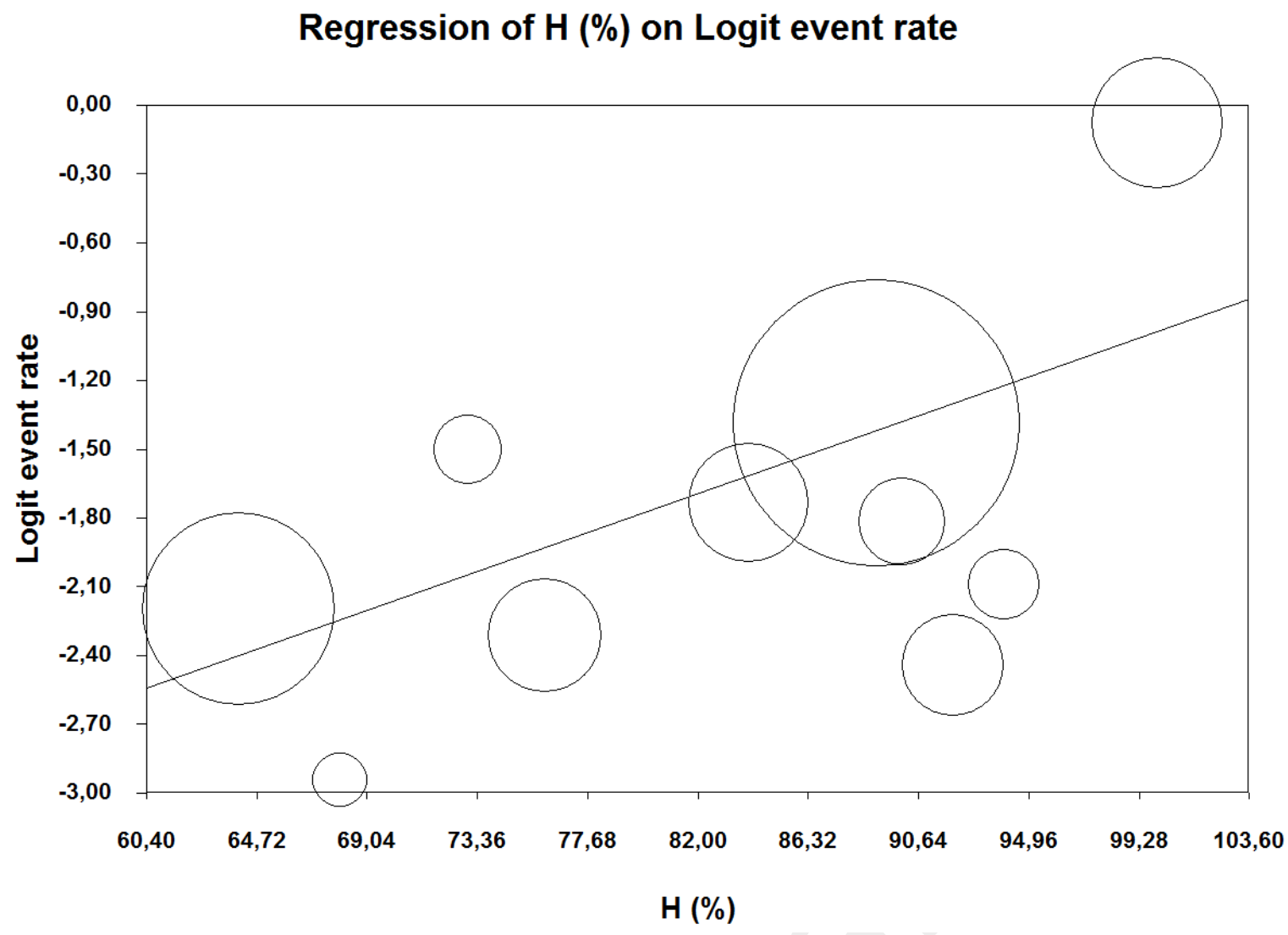

Fig. 1B

Figure 1B 


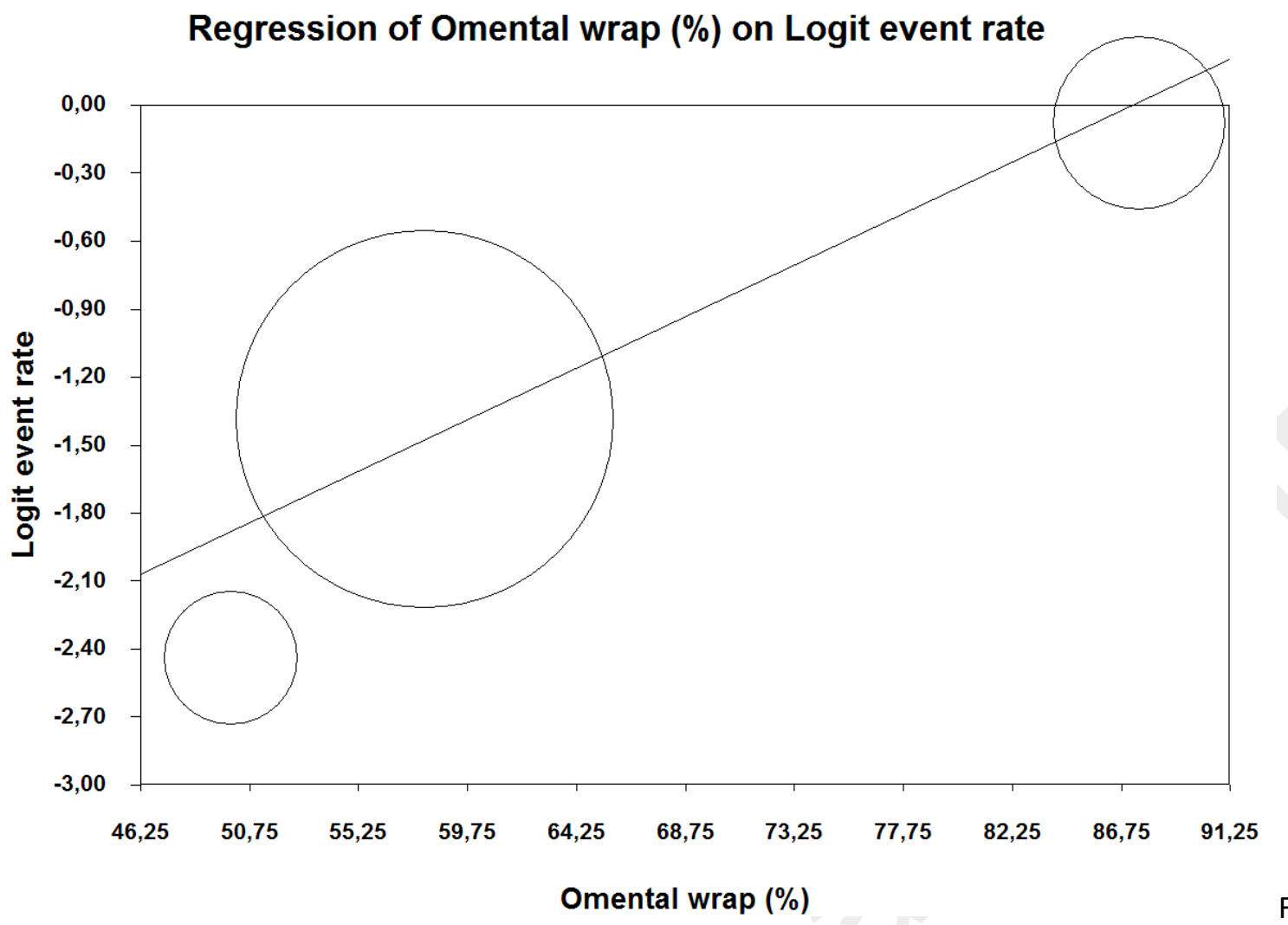

Fig. 1C

Figure 1C 


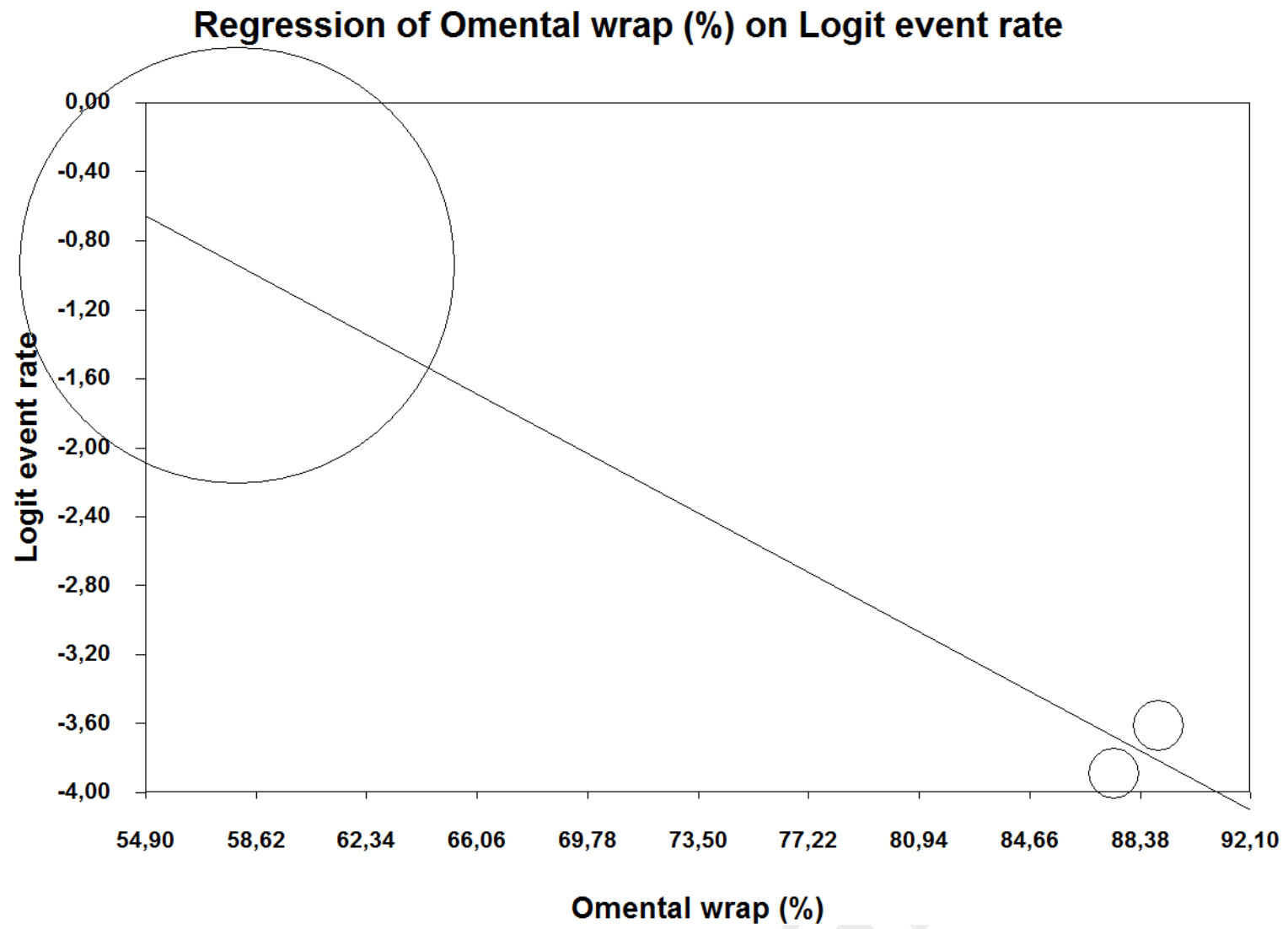

Fig. 1D

Figure 2 
Regression of Mean Age (year) on Logit event rate

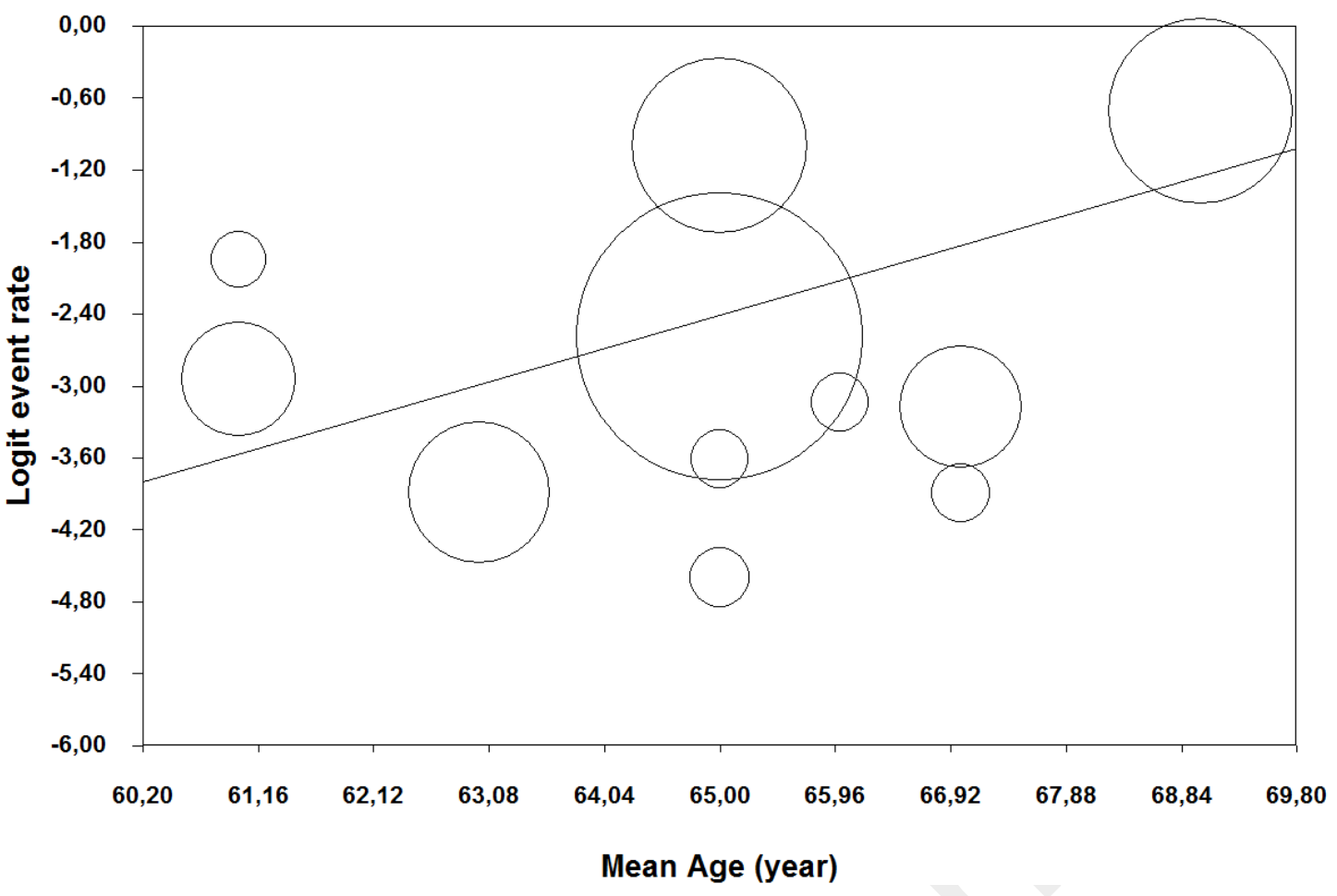

Fig. 2A

Figure 3A 
Regression of FDP (\%) on Logit event rate

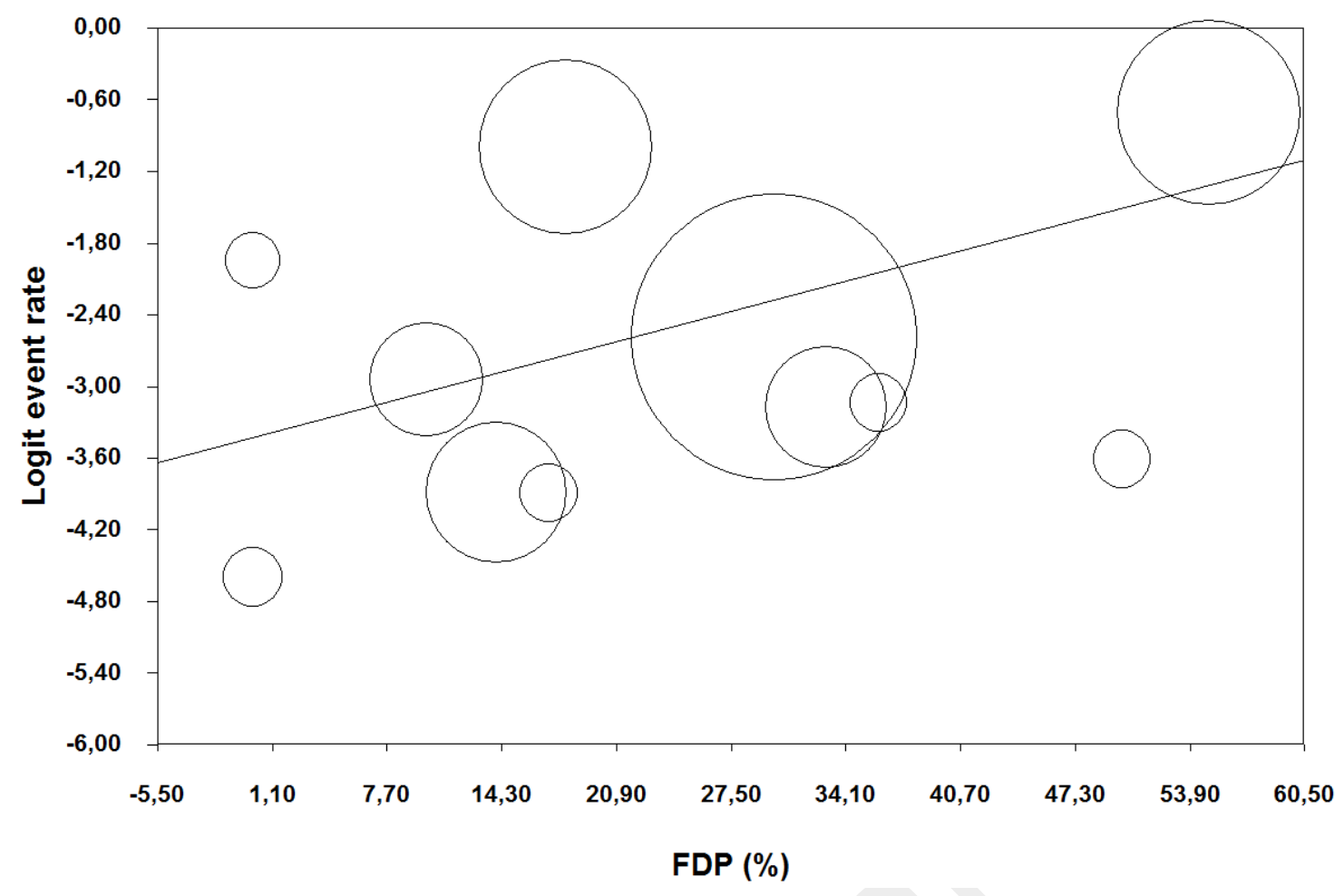

Fig. 2B

Figure 3B 
Regression of Virulent organisms on Logit event rate

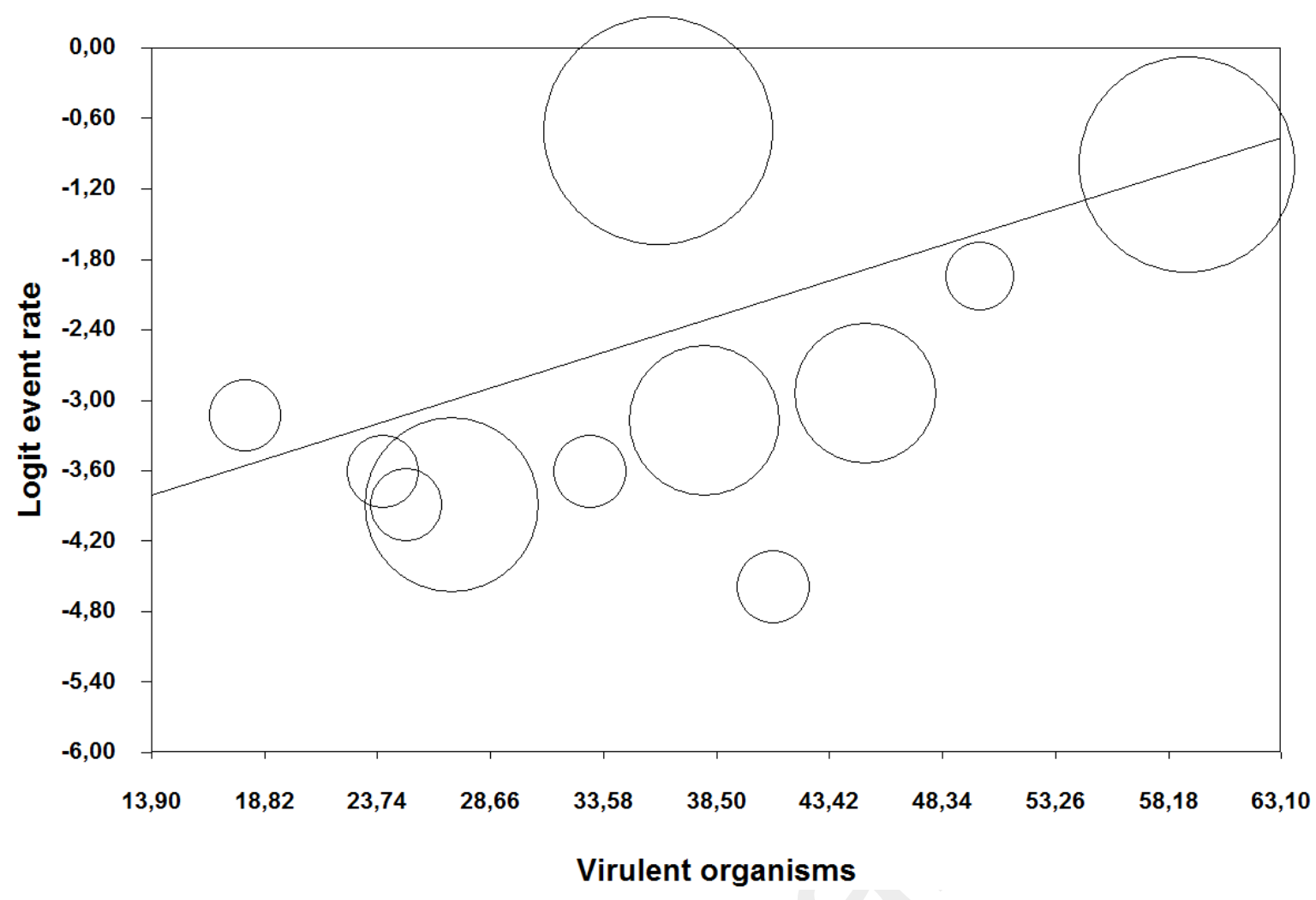

Fig. 2C

Figure 3C 
Regression of Non virulent organisms on Logit event rate

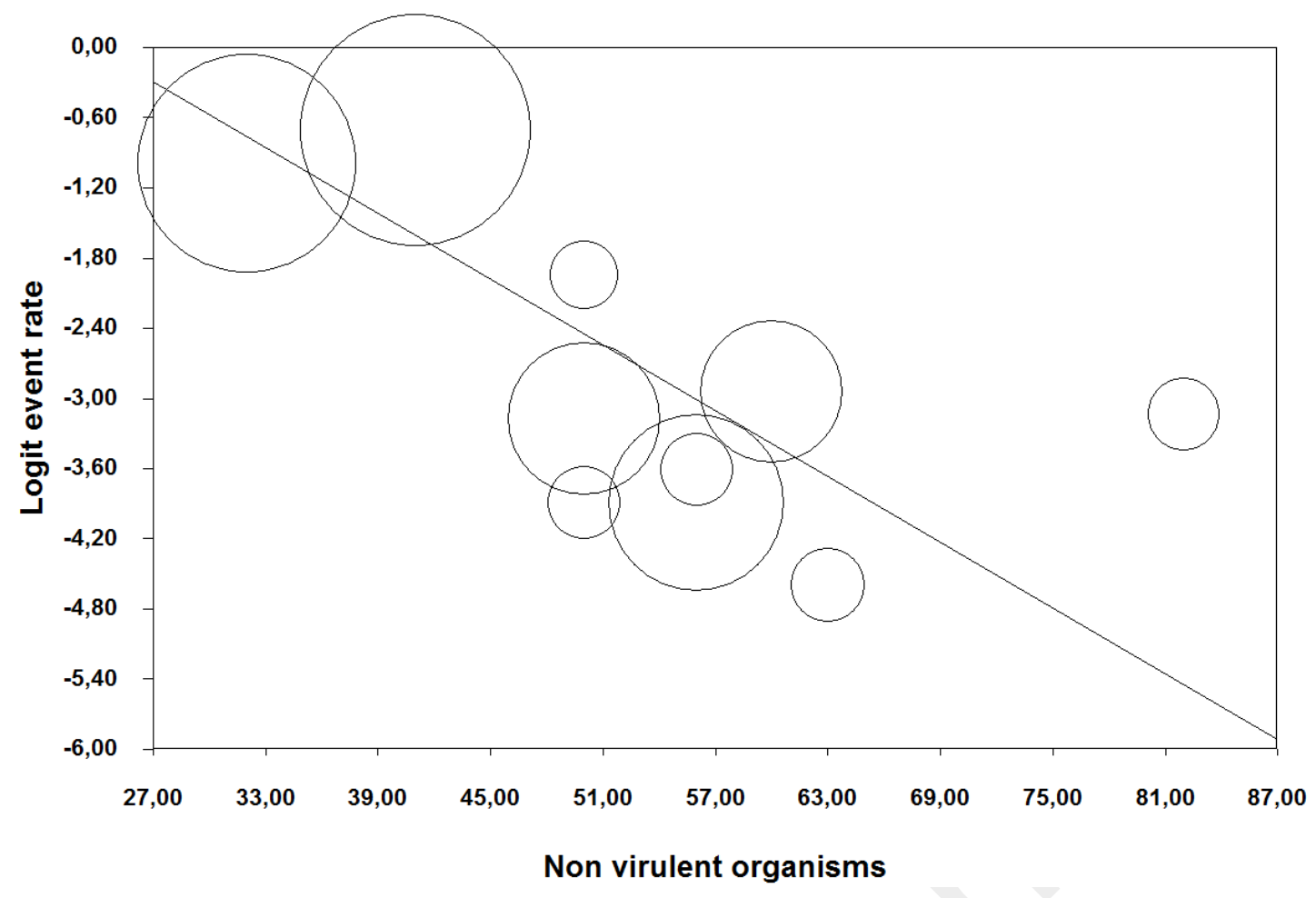

Fig. 2D

Figure 3D 


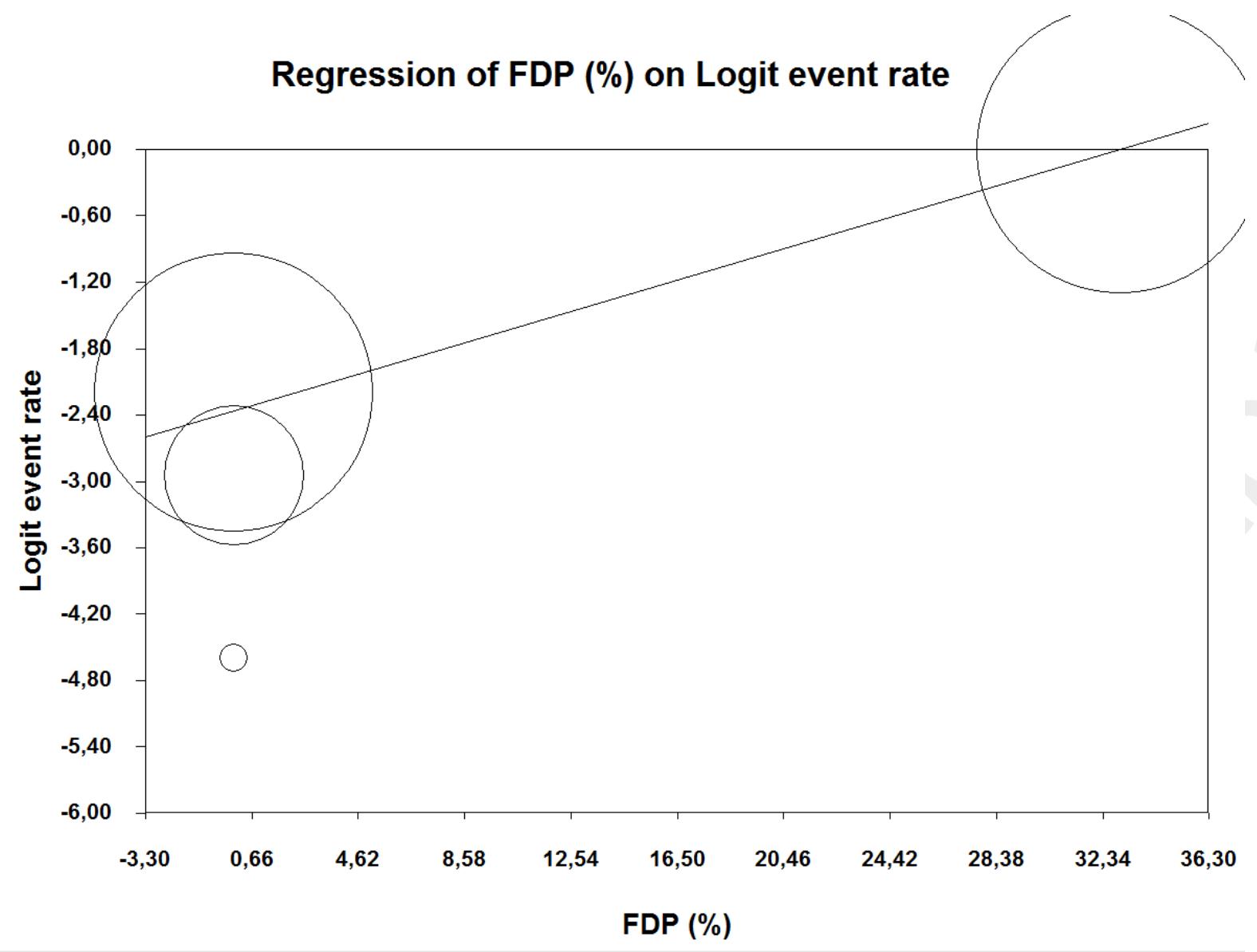

Fig. 2E

Figure 5 
Regression of Follow up (Mo) on Logit event rate

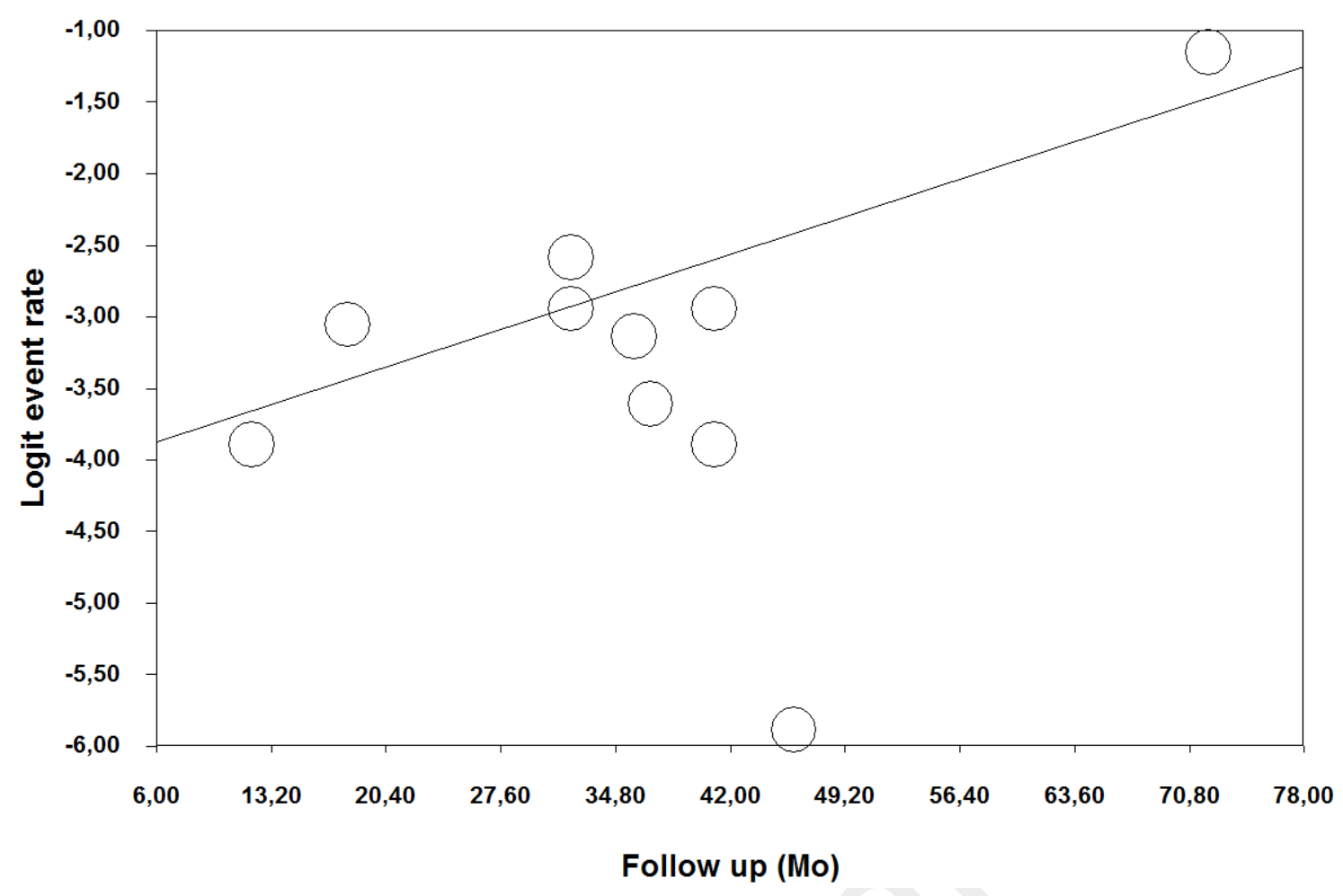

Fig. 3

Figure 4 
Supplementary Digital Material

Download supplementary material file: $\underline{J}$ Cardiovasc Surg-10669 1 V1 2018-07-02.docx 
Supplementary Digital Material

Download supplementary material file: $\underline{J}$ Cardiovasc Surg-10669 5 V2 2018-10-13.docx 
Supplementary Digital Material

Download supplementary material file: $\underline{J}$ Cardiovasc Surg-10669 6 V1 2018-10-13.docx 